Oleksandr Kashchuk

Uniw. im. Iwana Franki, Lwów

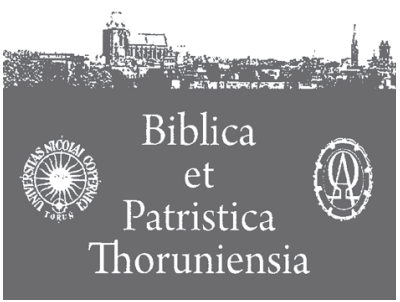

4 (2011) ISSN 1689-5150

\title{
Księga Rodzaju jako źródło duchowej inspiracji w Moralia in Iob św. Grzegorza Wielkiego
}

\section{The Book of Genesis as the source of spiritual inspiration in the Moralia in Iob of St. Gregory the Great}

Słowa kluczowe: Grzegorz Wielki, Moralia in Iob, Księga Rodzaju, duchowe doskonalenie, cnota, pokusa.

Key words: Gregory the Great, Moralia in Iob, The Book of Genesis, spiritual perfection, virtue, temptation.

Dapież Grzegorz Wielki (540-604)1 był człowiekiem, który poświęcił się doskonaleniu duchowego życia własnego oraz ludzi powierzonych jego duchowej opiece. Celem niniejszego artykułu jest przedstawienie myśli dotyczącej duchowego doskonalenia człowieka, zainspirowanej Księgą Rodzaju w dziele Grzegorza Wielkiego Moralia in Iob. W pierwszej części zostanie przedstawione omawiane dzieło jako skarbiec duchowych treści, a w drugiej zostaną przedstawione zaczerpnięte $\mathrm{z}$ Księgi Rodzaju treści związane z duchowym doskonaleniem człowieka.

\section{Moralia in Iob jako skarbiec duchowych treści}

Grzegorz Wielki był człowiekiem o charakterze ascetycznym² ${ }^{2}$ Bardzo ważną rolę w praktykowaniu ascezy w życiu Grzegorza Wielkiego odgrywało czytanie

1 Na temat aktualności myśli Grzegorza Wielkiego por. J. Leclercq, Actualité de Grégoire le Grand, w: Grégoire le Grand. Colloques internationaux du Centre National de la Recherche Scientifique, red. J. Fontaine, R. Gillet, S. Pellistrandi, Paris 1986, s. 681-684.

2 Por. Gregorius Magnus, Epistola ad Leandrum; tenże, In Librum Primum Regum I,61. Zob. R.A. Markus, Grzegorz Wielki, tłum. P. Nehring, Warszawa 2003, s. 88. 
Pisma świętego ${ }^{3}$. Nasz autor często podkreśla, że człowiek, który pragnie duchowo doskonalić się, powinien czerpać siły z mądrości słowa Bożego ${ }^{4}$. Według autora Moraliów, Pismo święte jest szczególnym źródłem łaski. Bez porównania przewyższa ono wszelką naukę i doktrynę. Przepowiada prawdę i przemienia serce czytelnika do umiłowania rzeczywistości niebiańskiej ${ }^{5}$. Im bardziej człowiek zgłębia bogactwo treści Pisma świętego, tym bardziej doskonali się w prawdziwej miłości i rozwija się duchowo. Im większego postępu dokonuje każdy chrześcijanin w zakresie poznawania Pisma, tym bardziej jego słowa znajdują wyraz i udoskonalają się w życiu chrześcijanina ${ }^{6}$.

Do postawy umiłowania Pisma przez Grzegorza Wielkiego, a zwłaszcza tych fragmentów biblijnych, w których znajdował treści pocieszające w cierpieniu, szczególnie przyczyniły się trudności otaczających go ludzi i osobiste ${ }^{7}$. Papież wyznaje, że osobiste cierpienie pomogło mu w zrozumieniu Księgi utrapionego Hioba ${ }^{8}$, w której temat cierpienia zajmuje szczególne miejsce ze względu na utrapionego bohatera komentowanej Księgi ${ }^{9}$. Głębokie rozumienie Księ-

3 Por. Gregorius Magnus, Epistola ad Leandrum 5. Zob. Markus, Grzegorz Wielki, s. 21-72; C. Dagens, Saint Grégoire le Grand. Culture et expérience chrétiennes, Paris 1977, s. 53.

4 Por. Dagens, Saint Grégoire, 268; P. Gwiazda, Życie kontemplacyjne wedtug św. Grzegorza Wielkiego, Warszawa 2001, s. 80-85; M. Porcel, La doctrina monastica de S. Gregorio Magno y la „Regula Monachorum”, Madrid 1951, s. 149-154.

5 Por. Gregorius Magnus, Moralia in Iob XX,1,1; tenże, Homiliae in Evangelia I,18,1. Zob. M. Casey, Spiritual Desire in the Gospel Homilies of Saint Gregory the Great, "Cistercian Studies" 16 (1981) 4, 311-312; Gwiazda, Życie kontemplacyjne, s. 77.83-84..

6 Por. Gregorius Magnus, Homiliae in Hiezechielem Prophetam I,7,8; tenże, Moralia in Iob XX,1,1. Zob. A. Tomkiel, Ojcowie Kościoła ucza nas modlitwy, tłum. Z. Zwolska, Warszawa 1995, s. 138-143; Ph. Delhaye, La morale des Pères, "Seminarium" 11 (1971) 3, 625-627; P.C. Bori, Circolarità e sviluppo nell'interpretazione spirituale: „Divina eloquia cum legente crescunt” (Gregorio M., In Hiez. I,VII,8), „Annali di storia dell' esegesi” 2 (1985) 263-274; B. Calami, S. Gregorio, maestro di formazione spiritualis, Seminarium 10 (1969) 2, 261-263.

7 Por. Markus, Grzegorz Wielki, s. 15-21; J. Leclercq, Miłość nauki a pragnienie Boga, tłum. M. Borkowska, Kraków 1997, s. 37-41; M. Starowieyski, Wstęp, w: Źródła monastyczne, t. 30: Grzegorz Wielki. Księga reguty pasterskiej, tłum. E. Szwarcenberg-Czerny, Kraków 2003, s. 14-15.

8 Por. Gregorius Magnus, Epistola ad Leandrum 5. Zob. Markus, Grzegorz Wielki, s. 34; L. Bielas, Życie codzienne papieża Grzegorza Wielkiego w świetle jego korespondencji, w: Charisteria Tito Górski Oblata, red. S. Stabryła, R.M. Zawadzki, Kraków 2003, s. 19-21; Starowieyski, Wstęp, s. 15-16.

9 Grzegorz Wielki miał szczególne zamiłowanie do tematu utrapienia. Wynika to z niektórych jego autobiograficznych wypowiedzi, gdzie utożsamia siebie z cierpiącym 
gi Hioba papież przekazuje w formie pisemnej. Wskutek tego powstają Moralia in Iob - najważniejsze dzieło Grzegorza Wielkiego, stanowiące komentarz do Księgi Hioba.

Moralia są uznawane za podstawowy podręcznik etyki w chrześcijaństwie zachodnim pierwszego tysiąclecia. Dzieło zostało ujęte w $35 \mathrm{ksiąg}$. Ma ono charakter encyklopedii teologicznej ${ }^{10}$. Jest wzorem religijnej medytacji o charakterze etyczno-egzystencjalnym ${ }^{11}$, źródłem etycznych i psychologicznych wiadomości na temat życia człowieka ${ }^{12}$. Moralia były początkowo konferencjami wygłoszonymi przez Grzegorza Wielkiego do mnichów w Konstantynopolu między rokiem 579 a 585, kiedy to nasz autor wyświęcony na diakona przez papieża Pelagiusza II (579) pełnił z jego polecenia funkcję apokryzjariusza, czyli nuncjusza ${ }^{13}$. Po przyjęciu przez św. Grzegorza obowiązków papieskich (590), dzieło zostało przez niego uzupełnione i otrzymało formę znaną do dzisiaj ${ }^{14}$.

Podstawowym elementem w metodzie wykładu zastosowanej przez Grzegorza Wielkiego w Moralia in Iob jest interpretacja Pisma świętego ${ }^{15}$. W Li-

Hiobem. Por. Gregorius Magnus, Epistola ad Leandrum 5; tenże, Homiliae in Hiezechielem Prophetam I,9,9; II,10,4; II,6,22-24. Zob. C. E. Straw, "Adversitas" et "Prosperitas": une illustration du motif structurel de la complémentarité, w: Grégoire le Grand. Colloques internationaux du Centre National de la Recherche Scientifique, red. J. Fontaine, R. Gillet, S. Pellistrandi, Paris 1986, s. 278.

10 Por. Dagens, Saint Grégoire, s. 53; P. Zacier, Analogie entre l'encyclopédie chrétienne des Moralia et l'enseignement du grammaticus: l'exemple de l’angélologie, w: Grégoire le Grand, s. 419-428.

11 Por. G. D’Onofrio, Historia Teologii, t. 2, tłum. W. Szymona, Kraków 2005, s. 49-50.

12 Por. S. Rosik, Grzegorz Wielki: Dzieła, w: Encyklopedia Katolicka, t. 6, red. J. Walkusz, Lublin 1993, kol. 325.

13 Por. R. Gillet, Introduction, w: Grégoire le Grand, Morales sur Job (I-II), ed. R. Gillet, SCh 32 bis, Paris 1975, s. 9-10.

14 Por. Markus, Grzegorz Wielki, s. 28; Leclercq, Miłość nauki, s. 36-37.

15 Odnośnie do korzystania przez Grzegorza Wielkiego z tekstu Pisma św. należy zaznaczyć, że we wstępie do Moraliów (Epistola ad Leandrum 5) nasz autor pisze, iż wykorzystuje on dwie łacińskie wersje przekładu - starą i nową. Stara wersja (Vetus Latina) jest tłumaczeniem, z którego korzystano przed dokonaniem tłumaczenia przez Hieronima, które nazywano nowym. W czasach Grzegorza Wielkiego korzystano jednak także ze starego tłumaczenia. Te dwie wersje przekładu Biblii niekiedy znacznie różniły się. Jeżeli to się zdarzało, Grzegorz preferował nowsze tłumaczenie, gdyż ono, jego zdaniem, jest bliższe oryginalnym językom. Por. G. R. Evans, The thought of Gregory the Great, Cambridge 1986, s. 88-89; J. Czuj, Papież Grzegorz Wielki, Warszawa 1948, s. 228. Szerzej na ten temat zob. J. Gribomont, Le texte biblique de Grégoire, w: Grégoire le Grand. Colloques internationaux du Centre National de la Recherche Scientifique, red. J. Fontaine, R. Gillet, S. Pellistrandi, Paris 1986, s. 467-471. 
ście do Leandra stanowiącym swoisty wstęp do Moraliów ${ }^{16}$, autor zaznacza, że w komentowaniu tekstów biblijnych będzie starał się wydobyć trojaki sens: historyczny (literalny), moralny (tropologiczny) i alegoryczny (typologiczny) ${ }^{17}$. Dodaje do nich niekiedy czwarty sens - mistyczny (anagogiczny) ${ }^{18}$. Grzegorz jednak nie zawsze troszczył się o precyzję terminologiczną i w wielu przypadkach był skłonny ograniczać wyżej wymienione sensy Pisma do dwóch, stosując rozróżnienie na znaczenie dosłowne i alegoryczne, które może mieć także charakter moralny ${ }^{19}$. Jego metodę egzegetyczną cechuje przede wszystkim troska o moralitas ${ }^{20}$, o czerpanie takiego użytku z Pisma świętego, by służyło ono celom wychowawczym, by prowadziło człowieka do umiłowania cnoty. Egzegeza i moralność u Grzegorza Wielkiego są nieodłączne: recepcja słowa Bożego musi prowadzić do wypełnienia go w życiu. Papież w przeważającej mierze zwraca uwagę na sens alegoryczno-moralny w celu wydobycia $\mathrm{z}$ tekstów duchowej treści dotyczącej życia moralnego i mistycznego. W Liście do Leandra nasz autor stwierdza, że dosłowny sens nie zawsze ujawnia pełną prawdę ${ }^{21}$. Nie należy jednak, jego zdaniem, lekceważyć tego sensu jako wstępnego etapu do alegorii ${ }^{22}$. Papież jednak nie stwierdza, że alegoria przewyższa literalne rozu-

16 Leander był biskupem Sewilli w Hiszpanii. Grzegorz zaprzyjaźnił się z nim w Konstantynopolu, gdy Leander przebywał tam z misją dyplomatyczną. Wysyłając do Leandra w 595 roku Moralia, Grzegorz Wielki dedykował mu list, który zawiera treści wprowadzające w lepsze zrozumienie dzieła. Por. Markus, Grzegorz Wielki, s. 196-199; Evans, The thought ..., s. 31.

17 Por. Gregorius Magnus, Epistola ad Leandrum 3. Zob. Dagens, Saint Grégoire, s. $62-65$.

18 Por. Dagens, Saint Grégoire, s. 62-65.

19 Por. Markus, Grzegorz Wielki, s. 64.

20 Por. Dagens, Saint Grégoire, s. 79.

21 Por. Gregorius Magnus, Epistola ad Leandrum 3. Zob. tenże, Moralia in Iob Praefatio,10,21. Por. Dagens, Saint Grégoire, s. 75.237-240.

22 Wielość sensów, wyprowadzanych podczas komentowania z Pisma świętego, jest znana u wcześniejszych pisarzy chrześcijańskich, spośród których w sposób szczególny wyróżniają się pod tym względem Orygenes i Augustyn. Por. M. Simonetti, Między dosłownością a alegorią, tłum. T. Skibiński, Kraków 2000. Szerzej na temat metody Grzegorzowej egzegezy por. Evans, The thought, s. 87-95; Markus, Grzegorz Wielki, s. 58-67; Dagens, Saint Grégoire, s. 55-81; G. Cremascoli, Lesegesi biblica di Gregorio Magno, Brescia 2001, s. 25-51; R. Manselli, Gregorio Magno e la Biblia, „Settimane di studio del centro italiano di studi sull'atto medioevo” 10 (1963) 67-101; J. M. Petersen, J.M., The „Dialogues” of Gregory the Great in their late antique cultural background, Toronto 1984, s. 25-55; G.A. Zinn, Exegesis and spirituality in the writings of Gregory the Great, w: Gregory the Great, s. 168-180; S. Zimdars-Swartz, A confluence of imagery: 
mienie, lecz pisze, że niekiedy po zdjęciu zasłony litery głębiej jest rozumiane przez ludzi to co wewnętrzne, a niekiedy zachowując przykrycie litery, ludzie dobrze korzystają z tego, co zewnętrzne ${ }^{23}$. Stąd Grzegorz Wielki w Moralia in Iob stosuje i alegoryczną, i literalną interpretację Biblii, czyniąć w ten sposób z własnego dzieła prawdziwy skarbiec duchowych treści.

W komentowaniu Księgi Hioba Grzegorz Wielki stosuje taką zasadę, że w celu głębokiego zakorzenienia swojego nauczania w Piśmie świętym wyjaśnia fragment komentowanej Księgi przytaczając jeden lub kilka innych fragmentów wziętych z różnych Ksiąg Biblii. Z tego powodu w Moraliach znajduje się wiele fragmentów, w których nasz autor odwołuje się między innymi do Księgi Rodzaju.

\section{Duchowe treści zaczerpnięte z Księgi Rodzaju w Moralia in Iob}

Idee, które papież czerpie z Księgi Rodzaju, szczególnie są bogate w treści duchowe, których przedstawieniu zostaje poświęcona ta częśc artykułu. Ukażemy je w pewnym logicznym porządku.

\subsection{Niebezpieczeństwo pokusy}

W nauczaniu Grzegorza Wielkiego zasadniczym niebezpieczeństwem dla duchowego wzrosu człowieka są pokusy diabła, dlatego według niego bardzo ważną rolę w duchowym doskonaleniu odgrywa rozstrzyganie myśli i dostrzeganie w nich początków pokus diabelskich. W celu potwierdzenia swojego przekonania nasz autor interpretuje w sposób alegoryczny fragment Księgi Rodzaju, w którym jest napisane, że potomstwo niewiasty zmiażdży wężowi głowę, a wąż zmiażdży mu piętę (Rdz 3,15). Według Grzegorza miażdżyć wężowi głowę oznacza dostrzegać początków diabelskich pokus i troszczyć się, aby one nie weszły do serca. Jeżeli diabeł zostaje odrzucony na początku kuszenia, to usiłuje pokonać człowieka powtórnie, czyli stara się zmiażdżyć piętę̨. Jeżeli uwaga ludzkiego umysłu chociaż raz zostaje zanieczyszczona przez pokusy, wtedy

Exegesis and christology according to Gregory the Great, w: Grégoire le Grand, s. 328; S. Rosik, Finalizm życia chrześcijańskiego w świetle twórczości papieża Grzegorza Wielkiego, Lublin 1980, s. 40-43; R.A. Markus, The Jew as a hermeneutic decise: The inner life of a Gregorian topos, w: Gregory the Great, s. 2-9; V. Recchia, Gregorio Magno papa ed esegeta biblico, Bari 1996.

23 Por. Gregorius Magnus, Moralia in Iob XXI,1,2.

24 Por. Gregorius Magnus, Moralia in Iob I,36,53. 
diabeł czuje się pewniej, ponieważ jeśli umysł człowieka chętnie przyjmuje pokusy diabła na początku kuszenia, później poddaje się przezwyciężony zupełnie. Jako potwierdzenie takiego przekonania papież przytacza opis kuszenia pierwotnego człowieka. Pisze, że w raju diabeł przekonywał go bardzo miłymi słowami, którym człowiek stopniowo poddawał się, co doprowadziło w końcu do całkowitego poddania się pokusie ( $\mathrm{Rdz} 3,5 \mathrm{nn}$ ). Kogo bowiem chociaż raz zachęci diabeł do współdziałania, tego później porywa nawet wtedy, gdy się on opiera i przezwyciężonego prawie gwałtownie duchowo zabija ${ }^{25}$.

Poskramianie pokusy przez człowieka na samym początku w momencie powstania Grzegorz Wielki nazywa opanowaniem grzechu swoim prawem. Odwołuje się on do następującego tekstu Księgi Rodzaju: Grzech leży u wrót i czyha na ciebie, ale ty masz opanować jego pragnienie i zawładnać nad nim ( $\operatorname{Rdz} 4,7)$. Wyjaśnia, że grzech leży u wrót, gdy człowiek odczuwa niepokojące kuszące myśli. Zostaje on opanowany tylko wtedy, gdy człowiek po rozpoznaniu tych myśli wyrzuca niegodziwość z serca i umysłem przezwycięża grzech ${ }^{26}$.

Rozważając nad Księgą Rodzaju papież przestrzega przed iluzorycznością diabelskich pokus. Stwierdza, że pokusy są wabiące, jednak są zwodnicze. Wydaje się bowiem, że diabeł obiecuje dobro, ale w rzeczywistości pociąga do zgubnego końca. Przekonanie to papież ilustruje przez odwołanie się do opisu kuszenia pierwotnego człowieka i opłakanych skutków poddania się temu kuszeniu. Pisze, że poddanie się pokusie spowodowało odrętwiałość umysłu pierwotnego człowieka. Jej symbolem jest dla Grzegorza Wielkiego cień, pod którym ukrył się Adam po spożyciu zakazanego owocu ( $\operatorname{Rdz} 3$ ). Unikając ciepła miłości, człowiek opuścił słońce prawdy i niejako ukrył się pod cieniem wewnętrznego, duchowego zimna. Utraciwszy ciepło miłości, człowiek znalazł się ukryty wśród drzew pod cieniem grzechu jakby pod zimnem wiatru $(\operatorname{Rdz} 3,8)^{27}$. Adam zlekceważył starannym rozpatrzeniem pokusy diabła, dlatego uwierzył, że zostanie przez niego przebóstwiony, natomiast utracił nieśmiertelność $(\mathrm{Rdz} 3)^{28}$. Diabeł sugerował pierwotnemu człowiekowi, że udzieli mu boskości, a uniósł nawet nieśmiertelność ( $\operatorname{Rdz} 3,5)$. Oszukiwał człowieka, że da mu to, czym nie jest, a odjął nawet to, czym by ${ }^{29}$. W pierwotnym człowieku, który poddał się pokusie, rodzaj ludzki upadł do nieszczęścia śmiertelnego życia i ciężkość winy popełnionej za pośrednictwem diabła odczuł przez ciężkość

25 Por. Gregorius Magnus, Moralia in Iob XVI,15,19; I,36,53.

26 Por. Gregorius Magnus, Moralia in Iob IV,19,36.

27 Por. Gregorius Magnus, Moralia in Iob XXXIII,3,5.

28 Por. Gregorius Magnus, Moralia in Iob XXXIII,25,45.

29 Por. Gregorius Magnus, Moralia in Iob XXXIII,9,17. 
swojego pokarania $(\operatorname{Rdz} 3,23)^{30}$. Człowiek odczuł Boże oburzenie utraciwszy prawdziwą wewnętrzną radość $(\operatorname{Rdz} 3,24)^{31}$. Przez pychę utracił stan, w jakim został stworzony, ponieważ uwierzył, że otworzą się jego oczy i stanie się jak bogowie $(\operatorname{Rdz} 3,5)^{32}$.

\subsection{Przezwyciężenie ziemskich pragnień}

Szatan, zdaniem Papieża, swoimi pokusami zawsze pragnie odwrócić człowieka od duchowego dążenia i nakłonić go do popełniania niegodziwości ${ }^{33}$. $\mathrm{W}$ tym celu chce posłużyć się także zewnętrznymi dobrami, które $\mathrm{z}$ istoty swej nie są wrogie wobec Boga, ale w których diabeł zawsze ukrywa swoje pokusy ${ }^{34}$. W nauczaniu Grzegorza Wielkiego diabeł zachęca człowieka do poddania się pokusom przez budzenie w człowieku pragnień przywiązujących go do dóbr tego świata, a oddalajacych od Boga ${ }^{35}$. Dlatego należy zachować ostrożność, aby te pragnienia nie dopuścić do zakorzenienia się w sercu. W Księdze Rodzaju papież znajduje szereg fragmentów, które świadczą o niegodziwości tych pragnień. Papież naucza, że pragnienie do umysłu wchodzi przez zmysły ${ }^{36}$. Jako

\footnotetext{
30 Por. Gregorius Magnus, Moralia in Iob XXIV,4,7.

31 Por. Gregorius Magnus, Moralia in Iob XXXIV,3,5.
}

32 Por. Gregorius Magnus, Moralia in Iob XXIX,8,18.

33 Por. Gregorius Magnus, Moralia in Iob XXXII,21,40.

34 Por. Gregorius Magnus, Moralia in Iob XX,38,73. Zob. Rosik, Finalizm, s. 82; L. Nieścior, Implikacje moralne nauki o czasie w „Moraliach” św. Grzegorza Wielkiego, „Teologia Patrystyczna” 2 (2005) 82.

35 Koniecznym warunkiem rozwoju duchowego pragnienia umożliwiającego łączność z Bogiem jest przede wszystkim postawa umysłowego wyrzeczenia się przywiązania przez miłość do spraw tego świata. Oczyszczenie i pogłębienie duchowego pragnienia wymaga odrzucenia ziemskich pragnień. U Grzegorza Wielkiego nie można pogodzić pragnienia, a więc miłości do dóbr ziemskich i duchowych, ponieważ obydwa rodzaje miłości wzajemnie się zwalczają. Człowiek, który miłuje ten świat, zupełnie zaniedbuje troskę o sprawy duchowe. Por. Gregorius Magnus, Homiliae in Avangelia I,17,14; I,19,5; I,5,2; tenże Moralia in Iob XVIII,9,16. Zob. P. Catry, Amour du monde et amour de Dieu chez Saint Grégoire le Grand, „Studia Monastica” 15 (1973) 2, 265-275; M. Casey, Spiritual Desire in the Gospel Homilies of Saint Gregory the Great, „Cistercian Studies” 16 (1981) 4, 299-301; Leclercq, Miłość nauki, s. 39.42; Gwiazda, Życie kontemplacyjne, s. 45.50-52; Rosik, Finalizm, s. 88-89; A. De Vogüé, The Views (I), „Cistercian Studies” 17 (1982) 1, 47-48; tenże, The Views (II), s. 218-220.

36 Autor Moraliów jest przekonany, że to, czy człowiek pozwoli się oszukać przez podstępy diabła, zależy od samego człowieka, od jego postawy w odniesieniu do odbieranych pokus związanych z ziemskimi darami. Papież kładzie akcent na rolę wolnej woli w podejmowaniu decyzji przez człowieka. Biskup Rzymu przyjmuje, że ludzka dusza przylega 
przykład podaje zmysł wzroku i stwierdza, że nie należy przypatrywać się do tego, czego nie można pragnąć. Ewa poddała się pożądliwości oczu, dlatego utraciła poczucie wewnętrznej prawości. Ujrzawszy drzewo, zwróciła uwagę, że jest piękne na widok i spożyła owoc z niego $(\mathrm{Rdz} 3,6)^{37}$. Aby więc umysł był czysty, należy powstrzymać oczy niejako porywaczy do winy. Ewa nie dotknęłaby zabronionego drzewa jeżeli najpierw nie oglądałaby je nieostrożnie, dopuszczając do serca pożądliwość ${ }^{38}$. Po grzechu pierwszych rodziców człowiek został szczególnie podatny na pożądliwość. Papież w sposób metaforyczny stwierdza, że grzech pierwotnego człowieka otworzył mu oczy pożądliwości, które ludzka niewinność trzymała zamkniętymi. Te oczy otworzył diabeł mówiąc: W jakimkolwiek dniu spożyjecie z tego drzewa, otworza się wasze oczy ( $\mathrm{Rdz} 3,5)$. W tym samym rozdziale Księgi Rodzaju stwierdza się, że Ewa sama skosztowała owocu i dała mężowi swojemu, a otworzyły się ich oczy (Rdz 3,6) ${ }^{39}$.

Potępiając ziemskie pragnienia, papież stwierdza, ze grzech Adama nawet wtedy się popełnia, gdy się pragnie czegoś małego i bezwartościowego. Diabeł rozumiał niegodziwość samego pragnienia, dlatego doprowadził pierwotnego człowieka do upadku nie przez pragnienie mięsa, a owocu (Rdz 3,6). Przykładem takiej postawy jest także Ezaw, który utracił chwałę pierworodnego syna, ponieważ bardzo pragnął marnej soczewicy (Rdz 25,33). Uznał ją za bardziej wartościową od pierworodztwa. Także w tym wypadku nie sam pokarm był niegodziwością, lecz pragnienie $\mathrm{go}^{40}$.

W kontekście przekonania, że należy przezwyciężyć ziemskie pragnienia, papież pisze, iż sprawiedliwi ludzie wiedzą, że w tym życiu są podróżującymi i gośćmi, dlatego nie usiłują umocnić się tu przez wewnętrzne przywiązanie do ziemskiej rzeczywistości. Nie tylko nie odczuwają oni niepokojów pragnień ziemskich, ale także unikają nadmiernego obciążenia troskami ziemskiego życia, ponieważ troski te zawsze stanowią pewną przeszkodę na drodze do łączności z Bogiem ${ }^{41}$. Natomiast niegodziwi ludzie, im bardziej oddaleni od nie-

(inhaerere) do ciała posiadającego zmysły (corporis sensus): wzrok (visus), słuch (auditus), smak (gustus), węch (odoratus) i dotyk (tactus). Te zmysły w nawiązaniu do alegorycznej interpretacji proroka Jeremiasza (Jr 9,21) uważa za okna (fenestrae), które są jakby jakimiś otworami, kanałami, przez które ludzki duch ma kontakt z zewnętrzną rzeczywistością. Por. Gregorius Magnus, Moralia in Iob XXI,2,4. Zob. Rosik, Finalizm, s. 77-80.

37 Por. Gregorius Magnus, Moralia in Iob XXXIV,15,26.

38 Por. Gregorius Magnus, Moralia in Iob XXI,2,4.

39 Por. Gregorius Magnus, Moralia in Iob V,31,54.

40 Por. Gregorius Magnus, Moralia in Iob XXX,18,60

41 Przywiązanie się do ziemskich spraw powoduje nadmierne troski i wewnętrzny niepokój, które stanowią przeszkodę w podniesieniu umysłu do duchowych wzniosłości. Papież przypomina ewangeliczną przypowieść o siewcy (Mt 13,22; Łk 8,7-8; Mk 4,7), która 
biańskiej ojczyzny, tym bardziej ukorzeniają myśli na ziemi przez pragnienie tego co ziemskie. Jako potwierdzenie swojego przekonania Grzegorz Wielki przywołuje postacie z Księgi Rodzaju - Henocha i Kaina. Wyjaśnia, że imię Henoch tłumaczy się jako „poświęcenie”. Henoch urodził się jako siódmy od początku istnienia ludzkości, a liczba „siedem” jest symbolem przyszłego życia. Łącząc tłumaczenie imienia Henoch z alegorią liczby „siedem” papież stwierdza, że to właśnie w rozumieniu sprawiedliwych ludzi Henoch rodzi się jako siódmy, ponieważ oni wpatrują się w przyszłość i poświęcają się życiu wiecznemu. Natomiast w rozumieniu niegodziwych ludzi, których typem jst Kain, Henoch rodzi się jako syn pierworodny. Kain nazywa pierwszego syna Henochem i od niego daje nazwę miastu, które założył ( $\operatorname{Rdz} 4,17)$, ponieważ wszyscy niegodziwi ludzie poświęcają się życiu ziemskiemu, które jest uprzednie w stosunku do życia wiecznego ${ }^{42}$. Według papieża w Księdze Rodzaju mówi się, że Kain jako pierwszy zbudował miasto na ziemi (Rdz 4,17) aby pokazać, że właśnie ten człowiek przez miłość umacniał się na ziemi, który był daleki od trwałości niebiańskiej ojczyzny ${ }^{43}$.

Mówiąc o przezwyciężeniu ziemskich pragnień, Grzegorz Wielki zwraca uwagę, że to przezwyciężenie wymaga nie wyrzeczenia się od wszelkich dóbr tego świata, lecz pozbycia się wewnętrznego przywiązania do nich przez miłość. Według naszego autora, wszystko, co Bóg stworzył, jest dobre. Samo posiadanie dóbr tego świata nie stanowi grzechu, natomiast przywiązanie do nich przez pragnienie jest grzechem. W tym zakresie biblijnym przykładem dla papieża jest Abraham. Był on człowiekiem bogatym, a jednak sprawiedliwym, ponieważ wyróżniał się pokorą i nie wynosił się z powodu bogactw. Przekonują o tym jego słowa: Jak będę mówił do swojego Pana gdyż jestem prochem i popiołem $(\operatorname{Rdz} 18,27)^{44}$. Podobnie jak Abraham, wielu ojców chociaż zajmowali się sprawami tego świata, a jednak pielęgnowali w sobie Boską mądrość. Tak Józef

ukazuje, że troski związane z uczuciowym przywiązaniem się do tego świata tłumią słowo Boże i pozbawiają je owocu. W przekonaniu autora Moraliów tylko spokojny umysł, niezajęty świeckimi myślami, może złączyć się z Bogiem. Por. Gregorius Magnus, Moralia in Iob V,11,19-20; XVIII,43,68; XXX,27,80; XVIII,43,68; XVIII,54,89; XXVII,13,25; XX,15,39-40. Zob. Gwiazda, Życie kontemplacyjne, s. 56-57; G. A. Zinn, Sound, silence and word in the spirituality of Gregory the Great, w: Grégoire le Grand. Colloques internationaux du Centre National de la Recherche Scientifique, red. J. Fontaine, R. Gillet, S. Pellistrandi, Paris 1986, s. 370; P. Daubercies, La théologie de la conditio charnelle chez les Maîtres du haut moyen âge, „Recherche de Théologie ancienne et médiévale” 30 (1963) 32-52.

42 Por. Gregorius Magnus, Moralia in Iob VIII,44,92.

43 Por. Gregorius Magnus, Moralia in Iob VI,6,7; XVI,10,15.

44 Por. Gregorius Magnus, Moralia in Iob X,30,49. 
zatroszczył się o cały Egipt w czasie głodu. Swoją umiętnością zachował życie nie tylko Egipcjan, lecz także wielu przybywających cudzoziemców (Rdz 42) ${ }^{45}$.

\subsection{Rozpusta cielesna}

Szczególnym rodzajem pragnienia wywołanego przez diabelskie pokusy Grzegorz Wielki uważa rozpustę cielesną, dlatego w sposób szczególny przestrzega przed poddaniem się jej. Powołując się na Księgę Rodzaju (Rdz 8,21), stwierdza, że myśl ludzkiego serca jest skłonna do zła cielesnej rozpusty od swojej młodości. Cielesne pragnienia zwiększają się wraz ze wzrastaniem wieku. Przestrzegając przed poddaniem się cielesnej rozpuście nasz autor pisze, że jeżeli człowiek dopuści do tego, aby wewnętrzna pokusa przejawiła się na zewnątrz, to zupełnie duchowo upadnie. Jeżeli bowiem człowiek nie zniszczy cielesnego pragnienia budząc w sobie lęk przed Bogiem, wszelkie dobro stworzonej natury upadnie w przepaśćc ${ }^{46}$.

Zagłębiając się w rozważania nad Księgą Rodzaju, Grzegorz Wielki naucza, że poddanie się cielesnym pragnieniom oznacza podwyższenie ciała ponad ducha. Papież pisze, że jeżeli ludzki duch jest poskramiany przed Bogiem, ciało nie podnosi się ponad ducha. Jeżeli zaś ludzki duch gardzi swoim Stwórcą, ciało, które ma być poddane duchowi, walczy przeciw niemu. Pierwotny człowiek znieważył ducha, dlatego odczuł znieważenie ciała. Jak tylko bowiem w pysze zgrzeszył, ukrył to, czego należy się wstydzić ( $\operatorname{Rdz} 3,7$ ). Nie chciał poddać się swojemu Stwórcy, dlatego utracił panowanie nad ciałem ${ }^{47}$.

Według Grzegorza Wielkiego zło cielesnej rozpusty dokonuje się albo w myśli, albo w uczynku. W tym kontekście papież odwołuje się do słów wypowiedzianych przez Pana do węża: Będziesz czołgał się na piersi i na brzuchu ( $\operatorname{Rdz} 3,14)$. Grzegorz wyjaśnia, że wąż czołga się na brzuchu, kiedy diabeł przez ludzkie członki dąży do spełnienia rozpusty w uczynku. Wąż czołga się na piersiach, kiedy tych, których nie może zmusić do ropusty w uczynku, zanieczyszcza w myśli. Mówi się więc, że wąż pełza najpierw na piersi, a później na brzuchu, ponieważ od nieczystej myśli przechodzi się do niegodziwego uczynku ${ }^{48}$.

45 Por. Gregorius Magnus, Moralia in Iob XVIII,43,69.

46 Por. Gregorius Magnus, Moralia in Iob XXVIII,19,43.

47 Por. Gregorius Magnus, Moralia in Iob XXVI,17,28: "Unde et ille primus inobediens mox ut superbiendo peccavit, pudenda contexit ( $\mathrm{Rdz} 3,7)$. Quia enim contumeliam spiritus Deo intulit, mox contumeliam carnis invenit. Et quia auctori suo esse subditus noluit, jus carnis subditae quam regebat amisit, ut in seipso videlicet inobedientiae suae confusio redundaret, et superatus disceret, quid elatus amisisset".

48 Por. Gregorius Magnus, Moralia in Iob XXI,2,5. 
Papież pisze, że pokusa cielesnej rozpusty może przemawiać do człowieka niejako stosując biblijny argument zaczerpnięty z Księgi Rodzaju. Może bowiem przekonywać go, że poddanie się cielesnej pożądliwości jest zgodne z Bożym ustanowieniem, ponieważ jeśliby Bóg nie zechciał aby mężczyzna łączył się z kobietą w cielesnym współżyciu, nie stworzyłby kobiety i mężczyzny na samym początku rodzaju ludzkiego $(\operatorname{Rdz} 1,27)^{49}$.

Grzegorz Wielki ukazuje grzech cielesnej rozpusty jako bardzo ciężki. Potwierdzeniem jego przekonania w tym zakresie jest fragment z Księgi Rodzaju, w którym opowiada się, że Pan zesłał na Sodomę i Gomorę deszcz ognia i siarki (Rdz 19,24). Papież wyjaśnia, że przez siarkę została oznaczona obrzydliwość ciała, a przez ogień - wewnętrzny płomień nieczystego pragnienia. Ponieważ człowiek zapalił się niegodziwymi pragnieniami związanymi z obrzydliwością ciała, należało, aby zginął jednocześnie przez ogień i siarkę. Postanawiając ukarać występek ciała, przez jakość kary Pan ukazał ciężkość grzechu ${ }^{50}$.

Zło cielesnej rozpusty, według papieża, należy przezwyciężać wspominaniem darów otrzymanych od Boga. Powołując się na Księgę Rodzaju Grzegorz Wielki stwierdza, że Józef odczuwał, iż kusi go pokusa rozpusty cielesnej. Pamiętał jednak o wszystkich darach, które otrzymał od Pana i tą pamięcią przezwyciężył zło (Rdz 39,8). W ten sposób otrzymaną łaskę zewnętrznych dóbr obrócił na broń cnót ${ }^{51}$.

Należy podkreślić, że Grzegorz Wielki potępia zło cielesnej rozpusty, ale nigdy nie potępia ludzkiego ciała i koniecznej troski o nie. Według niego, człowiek powinien troszczyć się o ciało o tyle, o ile wymaga konieczność, ale nie ponad miarę. Zdaniem papieża, dobrze o tym świadczy historia wyjścia Abrahama naprzeciw trzem aniołom ( $\mathrm{Rdz} 18$ ). Abraham wyszedł poza drzwi domu, natomiast Sara pozostała przy drzwiach. Według papieża, dom jest symbolem ludzkiego ciała. Intelekt człowieka jako pan i gospodarz domu w poznawaniu Trójcy przewyższa przeszkodę ciała i cielesny sposób życia. Żona Abrahama jest symbolem troski o ciało. Nie występuje ona poza drzwi, to znaczy nie troszczy się bardziej niż jest potrzeba, natomiast poskramia się we wstydliwości. Często jednak, gdy żonie mówi się nie pysznić, czyli nie pokładać nadziei w sprawach ziemskich, a zupełnie oddać zaufanie Bogu, lekceważy tym. Stąd ta sama Sara, gdy słyszy obietnice Boże dotyczące narodzenia dziecka, śmieje się. Później jednak zostaje zapłodniona. Papież podkreśla, że została ona zapłodniona nie w wieku młodym, a w podeszłym, ponieważ gdy przestała pokładać nadmierne zaufanie $\mathrm{w}$ trosce o ciało, wbrew nadziei i ludzkiemu rozumowi

\footnotetext{
49 Por. Gregorius Magnus, Moralia in Iob XXXI,45,90.

50 Por. Gregorius Magnus, Moralia in Iob XV,19,23.

51 Por. Gregorius Magnus, Moralia in Iob XXX,10,38.
} 
poczęła syna według obietnicy Boskiej. Dlatego syn został nazwany Izaakiem, czyli śmiechem, ponieważ gdy ludzki umysł nie pokłada nadziei w sprawach ziemskich, a przyjmuje ufność niebiańskiej nadziei, płodzi radość. Należy więc dbać o to, aby troska o ciało nie przekraczała granic konieczności i nie stała się powodem do pychy ${ }^{52}$.

\subsection{Wyznanie grzechów}

Ponieważ człowiek po upadku w grzech pierworodny został osłabiony przez pożądliwość, często poddaje się pokusom diabła i jest skłonny do grzechu, Grzegorz Wielki podkreśla konieczność wyznania grzechów po to, aby je zgładzićs ${ }^{3}$. Powołując się na fragment Księgi Rodzaju, w którym mówi się o zwiększeniu krzyku Sodomy i Gomory (Rdz 18,20), wyjaśnia, że każda niegodziwość jakby krzyczy przed Bogiem ${ }^{54}$. Stąd istnieje konieczność wyznania grzechów.

Według papieża wyznanie grzechów przez człowieka jest przejawem upokorzenia. Natomiast pełnienie grzechów, ukrywanie ich przez nie przyznawanie się do nich i powiększanie przez własną samoobronę jest przejawem pychy. Potwierdzenie swojej myśli papież znajduje w Księdze Rodzaju. Stwierdza, że pierwotny człowiek, kiedy dotknął zabronionego drzewa, zachował się od oblicza Bożego wśród rajskich drzew. Kiedy został skarcony przez Boga, odpowiedział, że sama kobieta dała mu owoc, czyli zanegował własną winę i obarczył nią kobietę $(\operatorname{Rdz} 3,12)$. Pośrednio zaś Adam obwinił Boga w tym, że żona, którą właśnie Bóg dał mu, stała się wykonawczynią grzechu. Kobieta natomiast powiedziała, że to wąż dał jej owoc, a ona zjadła $(\operatorname{Rdz} 3,13)$. Ewa więc pośrednio obwiniła Boga z powodu węża, którego właśnie On umieścił w raju (Rdz 3,5). Zarówno mąż jak i żona raczej bronili się niż wyznawali winę. W ten sposób zwiększyli ją. Bóg zapytał ich o to co popełnili po to, aby przez wyznanie ich winy zniszczyć ją. Zostali zapytani gdzie są, aby zrozumieli jak daleko znajdują się od Boga i wyznali swoją winę. Oni natomiast nie tylko nie wyznali winy, lecz nawet zechcieli uczynić sobie podobnymi Boga w grzechu. Grzegorz Wielki

52 Por. Gregorius Magnus, Moralia in Iob IX,66,106.

53 Por. Gregorius Magnus, Moralia in Iob XXVII,19,39-24,45; XXVII,16,32; IX,36,56; III,31,61; II,51,81; tenże, Homiliae in Hiezechielem Prophetam II,8,19. Zob. S. Rosik, Rola Kościoła jako zbawczej wspólnoty w doktrynie papieża Grzegorza Wielkiego, RTK 24 (1977) 3,36 .

54 Por. Gregorius Magnus, Moralia in Iob V,11,20. 
zwraca uwagę, że tylko wąż nie został zapytany o winę po to, aby nie dostąpił przebaczenia ${ }^{55}$.

Stosując typologiczną interpretację fragmentu Księgi Rodzaju, w którym mówi się o idolach ukrywanych przez Jakuba, papież podkreśla, że osobą nie potrzebującą wyznania grzechów był Chrystus. Wyjaśnia, że Jakub jest typem Chrystusa, Rakel - chrześcijan, Laban - diabła, a idoli - winy skąpstwa. U Jakuba Laban nie znachodzi idoli, ponieważ diabeł nie może znaleźć w Odkupicielu tego, co mógłby zganić. Rakel, która siedzi na idolach, jest symbolem potępienia winy skąpstwa przez chrześcijan przez pokutę $(\operatorname{Rdz} 31,35)^{56}$.

\subsection{Duchowe wzrastanie}

W nauczaniu Grzegorza Wielkiego człowiek przezwyciężając diabelskie pokusy i ziemskie pragnienia oraz wyznając grzechy odczuwa duchowy pokój, który umożliwia jego wewnętrzne wzrastanie. Papież jest przekonany, że sprawiedliwy człowiek im bardziej uciska niepokój związany z ziemskimi sprawami, tym bardziej rozpoznaje sprawy duchowe. Inspirację dla takiego przekonania nasz autor czerpie z fragmentu Księgi Rodzaju, w którym opowiada się, że Jakub podczas podróży układając się do snu, pod głowę podłożył kamień i zasnął. We śnie widział drabinę łączącą niebo z ziemią, Pana i wstępujących w górę oraz zstępujących na dół aniołów (Rdz 28,11-12). Papież tłumaczy, że droga jest symbolem ziemskiego życia, w którym człowiek pielgrzymuje do wieczności. Odpoczywać w drodze oznacza uśpić w sobie pragnienie tego co doczesne. Ujrzeć we śnie aniołów i Pana oznacza kontemplowanie rzeczywistości niebiańskiej po poskromieniu ziemskich pragnień. Podłożyć kamień pod głowę oznacza przylgnąć w umyśle do Chrystusa ${ }^{57}$. Człowiek więc wtedy duchowo łączy się z Bogiem, gdy oddala się od tego, co ziemskie.

Wewnętrzne wzrastanie przejawia się $\mathrm{w}$ zewnętrznym sprawiedliwym postępowaniu, ponieważ każdy, kto poskromił w sobie cielesny niepokój, powinien ćwiczyć umysł w uprawianiu świętego postępowania. W nawiązaniu do Księgi Rodzaju Grzegorz Wielki naucza, że każdy sprawiedliwy człowiek znajdujący się nawet wśród grzeszników pamięta, iż został stworzony na obraz i podobieństwo Stwórcy (Rdz 1,26), dlatego postępuje zgodnie z tym stanem ${ }^{58}$.

W Księdze Rodzaju Grzegorz Wielki znajduje przykłady, które są świadectwem praktykowania wielu cnót. O miłości i uniżeniu się przed słabością in-

\footnotetext{
55 Por. Gregorius Magnus, Moralia in Iob XXII,15,30; XXXIII,28,50.

56 Por. Gregorius Magnus, Moralia in Iob XXX,25,72.

57 Por. Gregorius Magnus, Moralia in Iob V,31,54.

58 Por. Gregorius Magnus, Moralia in Iob XXX,17,56.
} 
nego człowieka, według papieża, nauczają następujące słowa: Ziemia wydała kwitnąca trawe i dająca nasiona wedtug swego gatunku, a także drzewo rodzace owoce $[. .].(\operatorname{Rdz} 1,12)$ Papież wyjaśnia, że drzewo daje nasienie według swego gatunku, gdy nasz umysł ukierunkowuje się ku innemu człowiekowi i wydaje owoc dobrego postępowania ${ }^{59}$.

Cnota miłości w przekonaniu Grzegorza Wielkiego ma wiele oblicz, ponieważ chociaż jest jedna i ta sama miłość, jednak zapala umysł do niezliczonych uczynków. To właśnie miłość przez Abla ofiarowała wybrane dary Bogu i nie sprzeciwiając się wycierpiała miecz brata $(\operatorname{Rdz} 4,4.8)^{60}$. Abel jest dla Grzegorza Wielkiego wzorem człowieka, który cierpliwie znosił zło ze strony swoich bliźnich ( $\operatorname{Rdz} 4,8)$. Kto tego nie czyni, jest daleki od pełni dobra ${ }^{61}$.

Kontynuując omawianie cnoty miłości, papież pisze, że to właśnie miłość nauczyła Henocha prowadzić duchowy tryb życia i zabrała go do wzniosłęgo życia nawet $\mathrm{z}$ ciałem (Rdz 5,24). Miłość ukazała Noego jako jedynego miłego i doprowadziła go do zbudowania arki w wyniku długiego trudu oraz zachowała Noego dla świata (Rdz 7). Miłość przez Sema i Jafeta wstydziła się ojca i pokryła płaszczem to, czego nie należało oglądać ( $R d z$ 9,23). Ona podniosła prawicę Abrahama, którą w posłuszeństwie ofiarował syna na śmierć, i uczyniła go ojcem narodów (Rdz 22,10). Ona ubogaciła umysł Izaaka, którego zawsze trzymał w czystości, do widzenia tego, co nadejdzie w przyszłośći (Rdz 27,1). Ona zmusiła Jakuba $\mathrm{z}$ całego serca opłakiwać utratę dobrego syna i znosić obecność niegodziwych synów (Rdz 37,34). Ona nauczyła Józefa, sprzedanego przez braci, w niezniszczalnej wolności ducha znosić niewolę cielesną, a potem przewodniczyć tym braciom nie wynosząc się w umyśle (Rdz 42,33$)^{62}$.

Wielką wartość posiada cnota posłuszeństwa. Jest to, według Grzegorza Wielkiego, cnota, która przyszczepia inne cnoty umysłowi i je strzeże. Pierwotny człowiek otrzymał przykazanie, które miał zachowywać (Rdz 2) i jeżeli zehciałby w posłuszeństwie poddać się mu, do wiecznego szczęścia dotarłby bez wysiłku. Ponieważ jednak w nieposłuszeństwie postanowił wypelniać swoją wolę, odszedł od radości raju $(\operatorname{Rdz} 3)^{63}$. Grzegorz stwierdza, że cnota posłu-

59 Por. Gregorius Magnus, Moralia in Iob VI,35,54.

60 Por. Gregorius Magnus, Moralia in Iob X,6,9.

61 Por. Gregorius Magnus, Moralia in Iob XX,39,75.

62 Por. Gregorius Magnus, Moralia in Iob X,6,9.

63 Por. Gregorius Magnus, Moralia in Iob XXXV,14,28-32. Zob. S. Sojka, Ideat życia kapłańskiego w świetle pism świętego Grzegorza Wielkiego, Lublin 2003, s. 97-105; Porcel, La doctrina ..., s. 99-109; A. de Vogüé, The Views of St. Gregory the Great on the Religious Life in his Commentary on the Book of Kings (II), „Cistercian Studies” 17 (1982) 3, 230-231. 
szeństwa wymaga nie tylko spełnienia dobrych uczynków, ale także niekiedy ich zaprzestania. Wyjaśnia, że drzewo w raju, które człowiekowi Bóg zabronił dotykać, nie było złe (Rdz 2). Lecz aby przez posłuszeństwo człowiek dobrze stworzony wzrastał, został wstrzymany nawet od tego, co dobre, aby okazał się w większej pokorze poddany swojemu Stwórcy. Papież zwraca uwagę na słowa Księgi Rodzaju: Będziecie jeść $z$ każdego drzewa w raju, lecz nie dotykajcie drzewa poznania dobra i zła ( $\operatorname{Rdz} 2,16)$. Wyjaśnia, że jest konieczne, aby osoba, która zabrania poddanym jednego z jakichkolwiek dóbr, udzieliła im wielu innych, aby posłuszny umysł nie zginął, powstrzymując się zupełnie od wszystkich dóbr. Daltego Pan pozwolił spożywać owoce ze wszystkich drzew raju, jednak zakazał dotykać tylko jednego, ponieważ chciał żeby człowiek duchowo wzrastał ${ }^{64}$.

Wzorem człowieka, który pielęgnował cnotę posłuszeństwa jest dla Grzegorza Wielkiego Abraham. Abrahamowi Pan kazał wyjść ze swojej ziemi i zmierzać do nieznanej ziemi ( $\operatorname{Rdz} 12,1)^{65}$. Ze względu na osiągnięcie wiecznego dziedzictwa Abraham nie bał się ranić nawet dziedzica, którego otrzymał prawie umierający i w podeszłym wieku $(\operatorname{Rdz} 12,4 ; 22,2)^{66}$. Bóg bowiem wypróbowuje posłuszeństwo ludzi przez przepisy tego co ciężkie. Po wypróbowaniu Abrahama Pan rzekł do niego: Teraz poznałem, że boisz się Boga (Rdz 22,12) ${ }^{67}$.

Grzegorz Wielki podkreśla także wartość pokory. Według niego, człowiek powinien brać pod uwagę własną słabość i nie wynosić się z powodu dóbr, które otrzymał z łaski. Taką postawę zachowywał Abraham, który mówił: Czyż będę rozmawiał $z$ Panem moim, gdyż jestem prochem i popiołem (Rdz 18,27)? Papież naucza, że jeżeli Abraham, który został wywyższony aż do rozmowy z Panem, tak się uniżał, to wielką karę poniosą ci, którzy nie dorastają do tego, co duchowo wzniosłe, a jednak wynoszą się z powodu tego, co niskie ${ }^{68}$. Na przykładzie Abrahama papież naucza, że święci im bardziej udoskonalają się w poznaniu Boga, tym bardziej rozumieją, że są niczym w porównaniu z Bogiem ${ }^{69}$. Innym przykładem człowieka pokornego jest dla papieża Jakub, który kroczył pokor-

\footnotetext{
64 Por. Gregorius Magnus, Moralia in Iob XXXV,14,28.

65 Por. Gregorius Magnus, Moralia in Iob XXVIII,4,13.

66 Por. Gregorius Magnus, Moralia in Iob XXVII,10,17; XXXV,2,3.

67 Por. Gregorius Magnus, Moralia in Iob XXVIII,4,13.

68 Por. Gregorius Magnus, Moralia in Iob IV (III?),31,60.

69 Por. Gregorius Magnus, Moralia in Iob XVIII,50,82; XXXIII,38,67; XXIV,22,49; XXVII,46,76. Zob. Leclercq, Miłość nauki, s. 45; Porcel, La doctrina, s. 109-115; Gillet, Introduction, s. 66-67.93.
} 
nie naśladując stado owiec, a na przeciw wyszedł Ezaw wywyższając się licznym towarzystwem $(\operatorname{Rdz} 33,14)^{70}$.

Wzorem cierpliwości jest dla Grzegorza Wielkiego Izaak. Niesie on drewno przeznaczone dla własnego spalenia w ofierze, pyta się o ofiarę, następnie zostaje związany, nic nie mówi, zostaje pokładziony na ołtarz, a nie walczy ( $\mathrm{Rdz}$ 22,7). Wzorem pracowitości jest Jakub, który u krewnego Labana przebywał na służbie przez długi okres czasu ( $\mathrm{Rdz} 29)$. Wzorem czystości i wstrzemięźliwości jest Józef, który nawet jako niewolnik nie zechciał zostać zniewolonym przez rozkosz na pragnienie rozpustnej pani. Nawet w niewoli pozostał wolnym od niegodziwości ( $\operatorname{Rdz} 39,12)^{71}$.

Grzegorz Wielki podkreśla także wielkość postawy ofiarności. Naucza, że przedtem jak składać ofiarę, należy oczyścić umysł, ponieważ wszystko, co daje się Bogu, zostaje przez Boga przyjęte ze względu na umysł dającego. Ofiara powinna być miła ze względu na czystość ofiarodawcy. Papież odwołuje się do następującego fragmentu Księgi Rodzaju: Spojzał Bóg na Abla i jego dary, a na Kaina $i$ jego dary nie spojrzał ( $\mathrm{Rdz} 4,4-5)$. Zwraca uwagę, że zostało napisane, iż spojrzał Bóg najpierw na Abla, a potem na jego dary, a nie odrazu na dary, ponieważ Bóg przyjmuje ofiarę ze względu na serce ofiarodawcy. Nie Abel spodobał się Bogu ze względu na dary, lecz dary ze względu na Abla². Gdy zatem na ołtarzu serca człowiek przynosi Bogu ofiarę, należy zatroszczyć się, aby nieczyste duchy i niegodziwe myśli nie porwały tego, co umysł spodziewa się ofiarować Bogu. Przykładem w tym zakresie jest dla Grzegorza Wielkiego Abraham, który przy zachodzie słońca przynosząc Bogu ofiarę, gorliwie odpędzał ptaki, aby nie porwały przyniesionej ofiary. Interpretując ten tekst w sposób alegoryczny, papież pisze, że odpędzanie ptaków przez Abrahama oznacza walkę z niegodziwymi myślami ${ }^{73}$.

Papież podkreśla, że praktykowanie cnoty powinno prowadzić człowieka do kontemplacji rzeczywistości niebiańskiej. Źródłem inspiracji dla przekonania o łączności aktywnego i kontemplacyjnego życia jest dla Grzegorza Wielkiego fragment $\mathrm{z}$ Księgi Rodzaju, w którym opowiada się o Jakubie, który pełnił służbę ze względu na Rachelę, a przyjął Leę, ponieważ nie ma zwyczaju w ziemi Labana wydawać młodszą córkę wcześniej od starszej ( $\mathrm{Rdz} 29,26)$. Papież wyjaśnia, że Rachela oznacza kontemplację, natomiast Lea - aktywne życie. Rachela jest ładna, jednak niepłodna, natomiast Lea nie jest ładna, ale płodna. Tak samo, według naszego autora, ludzki umysł, gdy dąży do pokoju kontempla-

70 Por. Gregorius Magnus, Moralia in Iob VIII,44,92.

71 Por. Gregorius Magnus, Moralia in Iob XXVII,10,17; XXXV,2,3.

72 Por. Gregorius Magnus, Moralia in Iob XXII,14,28.

73 Por. Gregorius Magnus, Moralia in Iob XVI,42,53. 
cji, bardziej spogląda piękno duchowej rzeczywistości, ale mniej wydaje Bogu owoce w postaci działania. Gdy jednak ukierunkowuje się do działania związanego z przepowiadaniem, mniej spogląda piękno niebiańskiej rzeczywistości, ale bardziej wydaje owoce działania. Po połączeniu się z Leą Jakub przechodzi do Racheli, ponieważ każdy doskonały człowiek najpierw jest związany z aktywnym życiem, a później podnosi się do kontemplacyjnego ${ }^{74}$.

Aktywny sposób życia, w którym ukazują się cnoty człowieka Grzegorz Wielki metaforycznie nazywa grobem, ponieważ utrzymuje człowieka niejako martwego na złe uczynki. Aktywne życie ma jednak prowadzić człowieka do życia kontemplacyjnego, które jeszcze bardziej czyni człowieka martwym na złe uczynki, ponieważ całkowicie oddala go od spraw tego świata. Sprawiedliwy człowiek nie powinien lekceważyć żadnego z dwóch rodzajów życia, a powinien umiętnie połączyć je. Potwierdzeniem takiego przekonania jest dla naszego autora fragment Księgi Rodzaju, w którym jest napisane, że Abraham pochował małżonkę w podwójnym grobie (Rdz 23,19). Nasz autor wyjaśnia, że każdy doskonały człowiek niejako chowa swoją duszę jako martwą dla pragnień tego świata pod pokryciem kontemplacji i dobrego postępowania, aby uchronić ją od cielesnej pożądliwości ${ }^{75}$.

\subsection{Wzmaganie się diabelskich pokus}

Grzegorz Wielki jest przekonany, że im bardziej człowiek wzrasta w praktykowaniu cnoty i wzniesieniu się na wysokości, tym bardziej wzmacniają się przeciw niemu pokusy złego ducha ${ }^{76}$. Papież stwierdza, że diabeł codziennie nie przestaje robić tego, co zrobił w raju $(\operatorname{Rdz} 3,5)$. Usiłuje wydalić $z$ serca ludzi Boże słowa i umocnić w nim swoje pokusy. Groźby Pana dotyczące kary za grzechy diabeł przedstawia jako lekkie, usuwa lęk przed Boskim pokaraniem i zachęca do uwierzenia w to, co fałszywie obiecuje. Gdy obiecuje człowiekowi chwałę teraźniejszego życia, nie mówi nic innego, jak słowa wypowiedziane do pierwotnego człowieka: Spróbujcie i będziecie jak bogowie. Papież aktualizując te słowa wyjaśnia, że diabeł niejako mówi: Dotknijcie doczesnego pragnienia i okażecie się wyniośli w tym świecie ${ }^{77}$. Chociaż jednak sprawiedliwi ludzie

74 Por. Gregorius Magnus, Moralia in Iob VI,37,61.

75 Por. Gregorius Magnus, Moralia in Iob VI,37,56.

76 Por. Gregorius Magnus, Moralia in Iob II,61,66; IV,23,42; XXVI,6,9. Zob. Gwiazda, Życie kontemplacyjne, s. 70.112; Gillet, Introduction, s. 62-64; Rosik, Finalizm, s. 96.

77 Por. Gregorius Magnus, Moralia in Iob XXIV,7,14: "Nam cum praesentis vitae gloriam spondet, quid aliud dicit quam, Gustate, et eritis sicut dii? Ac si aperte dicat: Temporalem concupiscentiam tangite, et in hoc mundo sublimes apparete". 
przez prawość wyrzucają grzech z serca, ale diabeł pragnie znowu wrócić do niego. Na ten temat Grzegorz Wielki wypowiada się komentując następujący fragment Księgi Rodzaju: I stała się światłość. [...] Niechaj się stanie wieczór ( $\operatorname{Rdz} 1,3.5)$. Wyjaśnia, że Stwórca zawsze pzrewiduje ludzkie grzechy, dlatego Pismo ukazuje, iż światło chyli się ku wieczorowi, ponieważ po świetle prawości następuje ciemność pokusy. Nie mówi się jednak w Piśmie, że następuje noc, lecz wieczór, ponieważ światło sprawiedliwych ludzi nie zostaje zupełnie zgaszone przez pokusę. Często pokusa ukrywa światło sprawiedliwości w sercu sprawiedliwych ludzi, ale nie niszczy go ${ }^{78}$.

Grzegorz Wielki ukazuje szkodliwe działanie diabła na sprawiedliwych ludzi powołując się na fragment Księgi Rodzaju, w którym jest opisane, że Izaak u cudzego narodu kopał krynicę (Rdz 26,15), a Filistyni zasypywali ją ziemią. Wyjaśnia, że sprawiedliwy człowiek niejako cudzoziemiec znajdując się w nieszczęściu ziemskiego pielgrzymowania, przenika głębię swoich myśli. Zasypywanie krynicy przez Filistynów oznacza, że nieczyste duchy gdy widzą, iż człowiek rozstrzyga myśli, zwiększają pokusy ${ }^{79}$. W innym miejscu komentując ten sam fragment Księgi Rodzaju papież naucza, że kopanie studni oznacza zgłebianie przez sprawiedliwego człowieka rozumienia Pisma świętego. Zasypywanie studni przez Filistynów oznacza, że człowiekowi zmierzającemu na wysokości złe duchy wnoszą nieczyste myśli i niejako unoszą wynalezioną wodę Boskiej wiedzy ${ }^{80}$.

Dlatego papież stwierdza, że sprawiedliwy człowiek nieustannie powinien chronić umysł od pokusy, aby nie zniszczyła ona duchowego wnętrza człowieka i aby człowiek nie stał się niezdatny do pełnienia dobrych uczynków. Jako potwierdzenie swojego przekonania przytacza tekst z Księgi Rodzaju, w którym mówi się, że Bóg umieścił człowieka w raju, aby uprawiał go i doglądał (Rdz $2,15)$. Wyjaśniając te słowa papież pisze, że ten człowiek uprawia i dogląda raj, który czyni dobro, które postanowił i czuwa nad tym postanowieniem. Jeżeli zaś tylko uprawia raj, czyli postanawia czynić dobro, a nie dogląda go, czyli nie trwa w tym postanowieniu, to przychodzi niszcząca pokusa ${ }^{81}$.

Często jednak diabeł, gdy chociaż trochę wedrze się do serc ludzi dobrych, zostaje natychmiast wyrzucony przez niebiańskie pragnienia. Znajdując się bowiem na wysokim poziomie duchowego życia sprawiedliwy człowiek pokonuje wszystkie pokusy diabła ${ }^{82}$.

\footnotetext{
78 Por. Gregorius Magnus, Moralia in Iob VIII,10,21.

79 Por. Gregorius Magnus, Moralia in Iob XXXI,27,53.

80 Por. Gregorius Magnus, Moralia in Iob XVI,18,23.

81 Por. Gregorius Magnus, Moralia in Iob XIX,21,34.

82 Por. Gregorius Magnus, Moralia ion Iob XXXIII,3,6; XXVIII,21,45.
} 


\section{7. Źli ludzie jako naśladowcy diabła w kuszeniu sprawiedliwych ludzi}

Grzegorz Wielki jest przekonany, że diabeł często działa przeciwko sprawiedliwym ludziom za pośrednictwem osób niegodziwych, którzy są jego członkami. Tak według papieża Kain był członkiem Antychrysta przez zasługi (Rdz 4) ${ }^{83}$. W innym miejscu nasz autor stwierdza, że Laban był typem diabła, kiedy przyszedł z gniewem do Jakuba i szukał u niego swoich idoli ( $\mathrm{Rdz} 31$ ). Laban według Grzegorza Wielkiego interpretuje się jako wybielenie (dealbatio). Diabeł przyjmuje wybielenie, kiedy będąc ciemnym ze względu na zasługi, ukazuje siebie jako anioła światła (2 Kor 11,14). Służenie Jakuba Labanowi oznacza, że niegodziwi przedstawiciele narodu judejskiego służyli diabłowi. Można także przez Labana rozumieć ten świat, który prześladuje z gniewem Jakuba, ponieważ prześladuje wszystkich sprawiedliwych, którzy są członkami Chrystusa ${ }^{84}$.

Powołując się na Księgę Rodzaju Grzegorz Wielki ukazuje postacie, które odrzuciły cnotę i stali się naśladowcami diabła. W tym zakresie papież przede wszystkim przytacza osoby, które poddały się występkowi zazdrości. Według niego każdy, kto zazdrości, tym samym uznaje siebie za mniejszego od tego, komu zazdrości. Z powodu zazdrości diabeł kusił pierwotnego człowieka, ponieważ uznawał siebie za mniejszego przez utratę wiecznego błogosławieństwa. Pobudzony zazdrością Kain udał się do bratobójstwa i zabił tego, kogo uważał za lepszego od siebie (Rdz 4,5-7). Złościł się, że Pan zlekceważył jego ofiarę, a przyjął ofiarę Abla. Z powodu zazdrości także Ezaw zapalił się do prześladowania brata, ponieważ utraciwszy pierworodne błogosławieństwo, ubolewał, że jest mniejszym od tego, którego przewyższał przez urodzenie. Przez zazdrość Józef został sprzedany przez braci ( $\operatorname{Rdz} 37,27-28)$, ponieważ rozpoznawszy tajemnicę objawienia, usiłowali oni przeciwstawić się jego wzrostowi, aby nie stał się lepszym od nich ${ }^{85}$.

Papież jest przekonany, że źli ludzie są przeznaczeni dla duchowego oczyszczenia sprawiedliwych. Według niego tylko tacy ludzie są naprawdę dobrymi, którzy mogą przetrwać w stanie prawości także wśród złych ludzi. Powołując się na Księgę Rodzaju Grzegorz Wielki ukazuje, że w tym świecie niegodziwi są przemieszani ze sprawiedliwymi. Dwóch synów miał pierwotny człowiek sprawiedliwego i niegodziwego ( $\mathrm{Rdz} 4$ ). Trzech synów umieściła arka Noego - dwaj trwali w pokorze, a jeden upadł do wyśmiania ojca (Rdz 9). Dwóch synów miał Abraham - jednego niewinnego, a drugi był prześladowcą brata

\footnotetext{
83 Por. Gregorius Magnus, Moralia in Iob XXIX,7,15.

84 Por. Gregorius Magnus, Moralia in Iob XXX,25,72.

85 Por. Gregorius Magnus, Moralia in Iob V,46,84.
} 
(Rdz 16,15; 21,9). Dwóch synów miał Izaak - jeden trwał w pokorze, a drugi został odrzucony jeszcze zanim się urodził ( $\mathrm{Rdz} 25)$. Jakub miał dwanaście synów. Spośród nich jeden został sprzedany przez niwinność, a pozostali przez niegodziwość stali się sprzedawcami brata $(\operatorname{Rdz} 37,27)^{86}$. Zdaniem Grzegorza Wielkiego, nie trzeba bać się ludzi niegodziwych, ponieważ wyroki uczynione przez ludzką niegodziwość Pan zawsze wykorzystuje na wypełnienie swojego opatrznościowego planu. Świadczy o tym historia Józefa, którego bracia sprzedali do niewoli $(\operatorname{Rdz} 37)^{87}$.

\section{Summary}

The article discusses a question of spiritual thought of Gregory the Great based only on the Book of Genesis in the Moralia in Iob (Commentary on the Book of Job). According to Gregory the Great, the Holy Scripture is the fundamental Book from which the Christians should draw their ideas of spiritual life. To that purpose the Holy Scripture should be interpreted both allegorically and literally. Gregory the Great applied exactly such methods in his main work Moralia in Iob. That is why the Moralia are the real treasure of spiritual doctrine. Gregory the Great enriches the Commentary on the Book of Job with references to the other biblical books. Among them the Book of Genesis is one of the most alluded to. The fragments, in which Gregory the Great refers to the Book of Genesis, are especially abundant with spiritual content. In the article they are presented in certain consequent order. The spiritual perfection begins with the fight against temptations through which the devil endeavors to enslave the human being with allegation to the earthly goods. Since the human being is spiritually weakened and inclined to commit a sin, it is necessary to confess sins. Then the human being spiritually grows and his/her growing is manifested in the practice of virtues. The practice of virtues leads to the contemplation of the heavenly reality. The devil envies when the human beings spiritually grow, that is why he continually seduces the just person.

86 Por. Gregorius Magnus, Moralia in Iob XX,39,76.

87 Por. Gregorius Magnus, Moralia in Iob VII,18,28-29. 